\title{
Crypsis in early benthic phases of brachyuran decapod crustaceans in central Chile
}

\author{
Cripsis en fases bentónicas tempranas de crustáceos decápodos braquiuros en \\ Chile central
}

ÁLVARO T. PALMA ${ }^{1,2}$, CAEL ORREGO $^{3} \&$ MAURICIO ARRIAGADA $^{3}$

\author{
${ }^{1}$ Departamento de Ecología Costera, Facultad de Ciencias, Universidad Católica de la \\ Santísima.Concepción, Paicaví 3000, Casilla 297, Concepción, Chile; \\ e-mail: apalma@ucsc.cl \\ ${ }^{2}$ Center for Advanced Studies in Ecology and Biodiversity, Pontificia Universidad Católica de Chile, \\ Alameda 340, Casilla 114-D, Santiago CP 6513677, Chile \\ ${ }^{3}$ Departamento de Ecología, Pontificia Universidad Católica de Chile, Alameda 340, Casilla 114-D, \\ Santiago, Chile
}

\begin{abstract}
Although common and in some cases of commercial value, little is known about the mechanisms and processes that affect the distribution and abundance of many species of decapod crustaceans, particularly in Chile. All of these species have planktonic larvae that must settle and recruit before becoming part of the adult segments of their populations. For several of these species we have detected the presence of a variety of color morphs in newly settled individuals. The existence of these morphs in Chilean species is comparable with those observed in other latitudes (e.g., coast of the Gulf of Maine). On the other hand, it is characteristic that the occurrence of these patterns only appears during the early juvenile stages and that after reaching a certain size it disappears, with adults being typically monochromatic. The expression of this pattern in the Chilean subtidal seems to be more pronounced in detritivorous species than in carnivorous ones. We propose that the existence of these kind of phenotypic attributes, apparently generalized in brachyuran decapods, could play an important role both from an ecological as well as evolutionary point of view.
\end{abstract}

Key words: crypsis, behavior, Brachyuran Decapods, settlement, recruitment, central Chile.

\section{RESUMEN}

Aunque comunes, y en algunos casos de valor comercial, poco es lo que se conoce acerca de los mecanismos y procesos que afectan la distribución y abundancia de muchas especies de crustáceos decápodos, particularmente en Chile. Todas estas especies poseen larvas planctónicas que deben asentarse y reclutar antes de pasar a formar parte de los segmentos adultos de sus poblaciones. En varias de estas especies hemos detectado la presencia de una variedad de morfos de coloración en individuos recién asentados. La existencia de dichos morfos en especies chilenas es comparable con aquellos observados en otras latitudes (e.g., costa del Golfo de Maine). Por otro lado, es característica la aparición de estos patrones solo durante los estadíos juveniles tempranos y, al alcanzar cierto tamaño, estos desaparecen, siendo los adultos típicamente monocromáticos. La expresión de este patrón en el submareal chileno parece ser más pronunciada en las especies detritívoras que en las carnívoras. Proponemos que la existencia de este tipo de atributos fenotípicos, aparentemente generalizado en decápodos braquiuros, podría jugar un rol importante, tanto desde un punto de vista ecológico como evolutivo.

Palabras clave: cripsis, comportamiento, decápodos braquiuros, asentamiento, reclutamiento, Chile central.

\section{INTRODUCTION}

The ability of many organisms to avoid predation is fundamental from an ecological as well as an evolutionary perspective. This is particularly important if organisms undergo important changes in size, smaller individuals being more susceptible to predation. This is the case of many marine benthic decapod crustaceans, where individuals undergo a planktonic larval phase that ends at the time of settlement and recruitment. Without underestimating the degree of mortality that affect individuals while part of the plankton, mortality of decapods is typically high soon after settlement, especially through visual predation exerted by fish (Whale \& Steneck 1992, Beck 1995, Stachowicz \& Hay 1996, Palma et al. 1998). Since marine decapods are particularly vulnera- 
ble to predators at the time of and just after settlement, mechanisms that mediate predation may be critically important to the demography and possibly the evolution of the species. A common anti-predatory strategy utilized by decapods at the time of settlement include the use of structural refuges (Wahle \& Steneck 1992, Beck 1995, Stachowicz \& Hay 1996), however, less well known are examples of visual crypsis (Palma \& Steneck 2001). In this latter type, small newly settled individuals, display color patterns that resemble those of the surrounding environment (Endler 1978). These species typically settle into shallow coastal areas where the substrate is dominated by different grain size material ranging from fine sediment and shellhash to cobble and boulder. Although the expression of visual crypsis is common among other small marine crustaceans (e.g., Hacker \& Madin 1991, Guarino et al. 1993, Espoz et al. 1995, Merilaita 1998), it has not been widely demonstrated for Decapods. Exceptions to this are the particular and well-documented case of decorating behavior of crabs in the family Majidae (Cruz-Rivera 2001) or the cases describing the existence of color morphs during juvenile stages of Carcinus meanas (Hogarth 1978) and Cancer irroratus (Palma \& Steneck 2001).

Recognizing that most Decapods are vulnerable to predation during these early, usually small benthic stages, suggests that crypsis, as defined by Endler (1978), should be maximized in the microhabitat where the prey is most vulnerable to predation. In this context, theoretical approaches have been developed that support the optimization of crypsis in heterogeneous habitats (Merilaita et al. 1999) and the value of maintaining color polymorphisms like the one described here (Endler 1988).

Several decapod species are common inhabitants of the shallow subtidal environments of the coast of central Chile. Within this system, we discovered and quantified the existence of color polymorphism among the newly settled and juvenile size classes of several decapod crustaceans. Individuals displayed colors and color patterns different from those of adults, which are unvaryingly monochromatic. Among the species with this attribute are six Anomurans and eight brachyurans from which we identified carnivorous and detritivorous ones. For all species, the color variation among newly settled individuals decreased as size increased. We hypothesized that the existence of this color polymorphism is related with a defense mechanism against predators.
The objective of this study was to quantify the degree of color polymorphism among different species of crustacean decapods that are common in shallow subtidal environments along the central coast of Chile.

\section{MATERIAL AND METHODS}

\section{Field surveys and data gathering}

Field surveys were made at four sites along the coast of central Chile, from north to south: Las Docas, Quintay, Punta de Tralca, and Las Cruces (Fig. 1), between February 1999 and November 2000. All sites corresponded to rocky shores where the presence of suitable substrata for decapods is common. In all sites, the abundance of all decapods was quantified through visual and air-lift suction sampling SCUBA surveys. The former method is primarily used to estimate the abundance of larger, less cryptic individuals. For this, $1 \mathrm{~m}^{2}$ square frames were haphazardly placed over specific types of habitat (cobble/boulder substrate) at an average depth of $10 \mathrm{~m}$ BMLW. All specimens found within the area were in situ identified, their carapace width measured and sex determined, and then released (see Palma et al. 1999 for methodological details).

Smaller or newly settled Decapods were quantified through the use of an underwater airlift device (for details on the air-lift suction sampling procedure see Wahle \& Steneck 1991, and Palma et al. 1998). This instrument allows a thorough sampling of the smaller and often cryptic Decapods. During these surveys, smaller $(0.25$ $\mathrm{m}^{2}$ ) square frames were placed on cobble substrata that were overturned in order to capture all individuals. Individual samples were stored in mesh bags for their analysis in the lab. All individuals were identified, measured and their sex determined when possible. The color or color pattern of the carapace of each individual was recorded following a standardized criterion (see Palma \& Steneck 2001) in which crabs colored differently than the adults were identified and labeled accordingly. The first capital letter in the color classification scheme corresponds to the main background color observed in the carapace, followed by lower case letters, which identify the secondary color patterns (all the labeling was made in Spanish). Even though the criterion utilized to identify and describe the different color morph expressions is arbitrary, it was the same procedure followed throughout. We operationally defined newly settled crabs as those with $<10-$ mm of carapace width. 

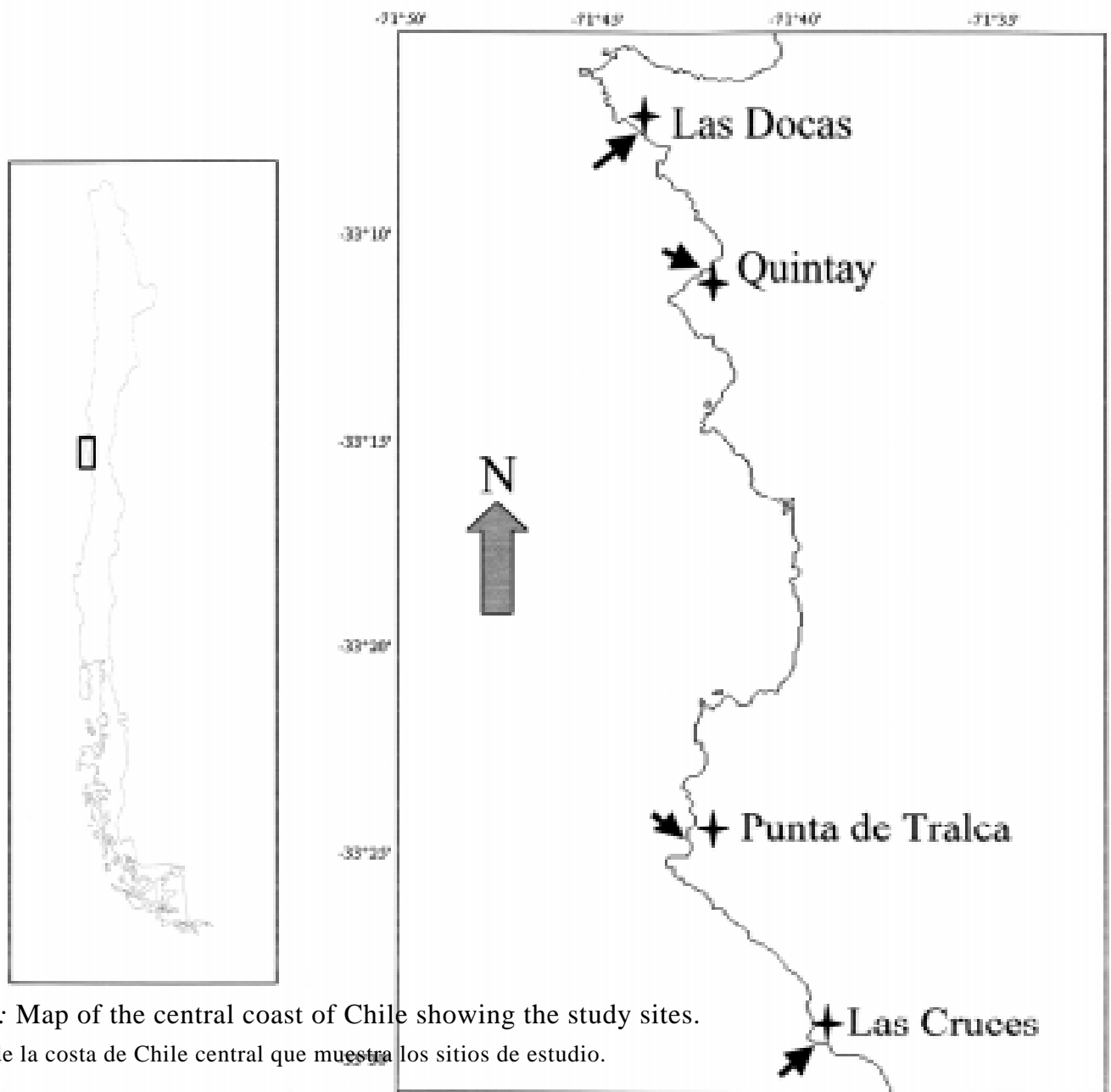

Fig. 1: Map of the central coast of Chile showing the study sites. Mapa de la costa de Chile central que muestra los sitios de estudio.

Parametric statistics were used throughout the study utilizing the statistical program SYSTAT (1992). The assumptions of normality, homogeneity of variance, and independence of observations were tested and appropriate transformations were performed when necessary (Zar 1999). A significance level of $P \leq 0.05$ was considered throughout the study.

\section{RESULTS}

\section{Distribution and abundance of Decapods}

Only six species of large brachyuran Decapods were found at the four sites surveyed through visual censuses. The average abundance did not surpass 5 individuals $\mathrm{m}^{-2}$ with Paraxanthus barbiger (Poeppig, 1836) being the most abundant one (Fig. 2). On the other hand, the result of the bottom suction samples obtained at the same four sites show that, both diversity and abundance, were much higher. Overall we found species belonging to three major decapod categories; five Anomurans, eight Brachyurans and two shrimps (Fig. 3). Although diverse in general, two species in particular were the most abundant (Allopetrolisthes angulosus (Haig 1960) and Paraxanthus barbiger for Anomurans and Brachyurans, respectively), reaching well over 100 individuals $\mathrm{m}^{-2}$ in some cases. As found in the visual surveys, $P$. barbiger was the most abundant brachyuran in these systems. Comparing the abundance of the six brachyuran species obtained by the two surveying methods, the difference in abundance was significant $\left(F_{1,46}=7.97, P=0.007\right)$. 

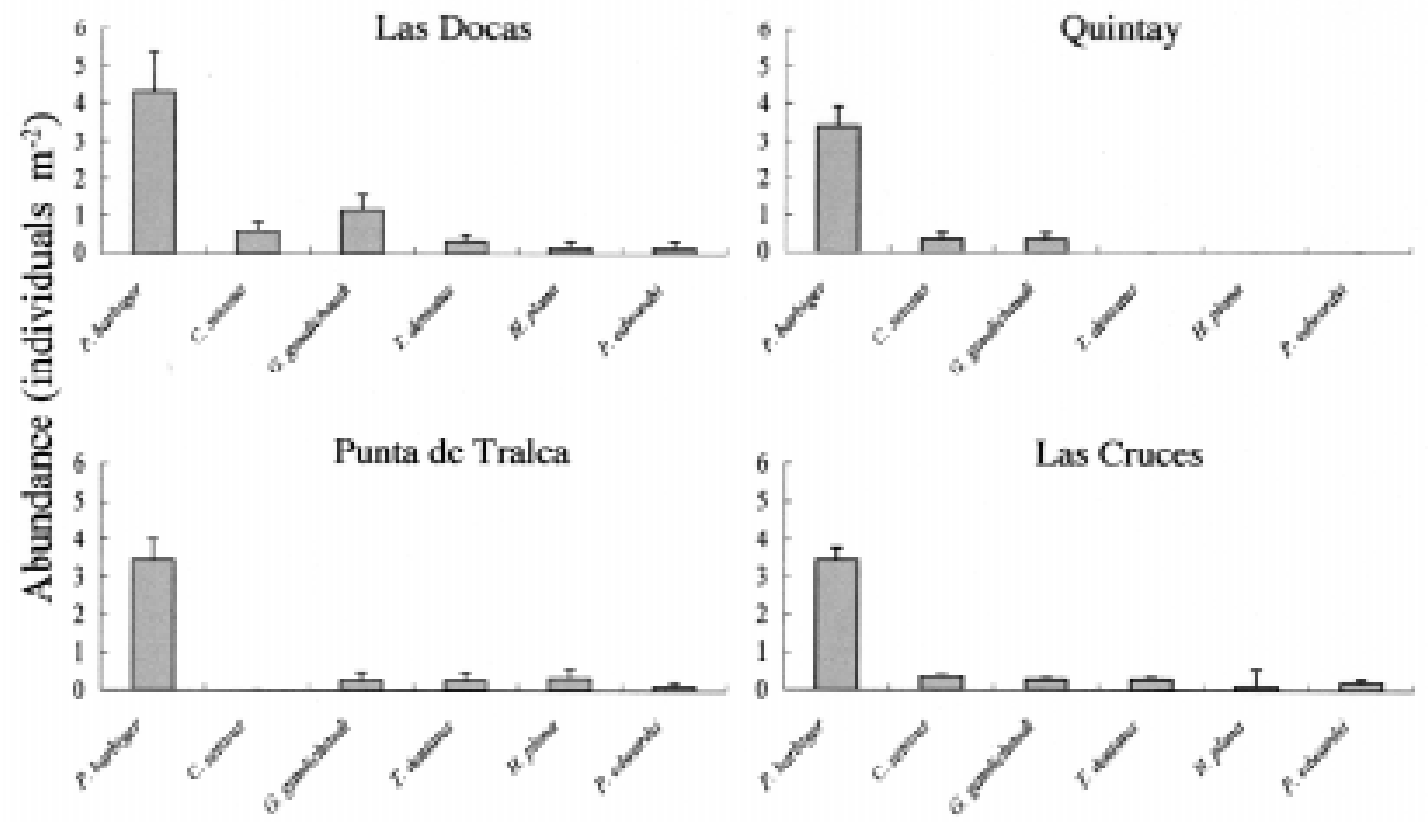

Fig. 2: Abundance of six decapod crustacean species obtained through visual surveys at the four study sites. Numbers represent individuals found in $1 \mathrm{~m}^{2}$ frames placed on boulder substrate. Error bars represent $\pm 1 \mathrm{SE}$.

Abundancia de especies de crustáceos decápodos obtenida de censos visuales efectuados en los cuatro sitios de estudio. Los números representan a los individuos encontrados al interior de cuadrantes de $1 \mathrm{~m}^{2}$ ubicados sobre sustrato de bolones. Las barras de error representan $\pm 1 \mathrm{EE}$.

\section{Color variants of Decapods}

All juvenile individuals of decapod species encountered during our surveys displayed several color variants different from those displayed by their respective adult. The total number of individuals found was of 5,250 (1,821 Anomurans and 3,429 Brachyurans, Fig. 4). The number of color variants present in these species ranged from 4 in Allopetrolisthes punctatus (Haig, 1960) up to 65 in Paraxanthus barbiger. The average degree of variability was greater for Brachyurans $(17.5 \pm 19.5)$ than for Anomurans $(9.4 \pm 5.7)$, especially since most of the variability observed in the former was given by the high degree of variability detected in $P$. barbiger (Fig. 4). The expression of these color variants was even more pronounced in smaller individuals as exemplified by the variation of this attribute at different size classes of P. barbiger collected at Quintay (Fig. $5)$. The combined proportion of individuals with non-adult color was significantly greater in the first three smallest size classes compared to any of the larger size classes $\left(\mathrm{F}_{3,188}=7.843, \mathrm{P}<\right.$ $0.0001)$.

\section{DISCUSSION}

Important differences in composition (diversity and relative abundance) can be detected when different collecting methods, such as visual and suction sampling, are employed for the assessment of subtidal decapod assemblages (Palma et al. 1998). However, each technique is aimed to answer different types of questions. In this study, visual surveys only show a small fraction of the assemblage composition but include larger individuals (Fig. 2). On the other hand, suction samples allow a more precise detection and quantification of the smaller fraction of these decapod assemblages, including newly settled individuals and other groups such as anomuran and shrimp species, which would otherwise pass undetected (Fig. 3). The samples obtained by the latter technique also show phenotypic differences (i.e., color morphs), mainly present only during the early benthic phases of most of these species. The presence of color variants (different from the adult coloration) was detected in 13 of the species considered. Although not statistically significant $\left(\mathrm{F}_{1,11}=0.846, \mathrm{P}=0.3773\right)$, the occurrence of morphs tends to be more abundant in Brachyurans (17.5 \pm 19.5$)$ than in Anomurans (9.4 \pm 5.7 ) (Fig. 4). In all the species examined, the more diverse 

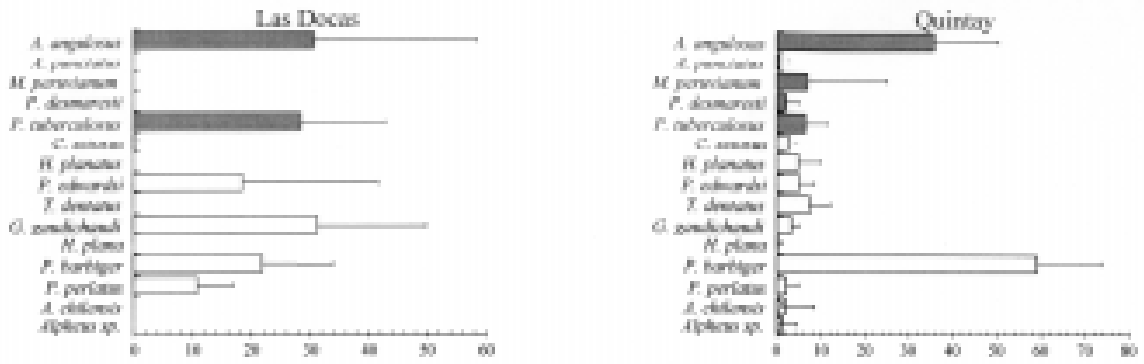

Anomuran Brachyuran shompis
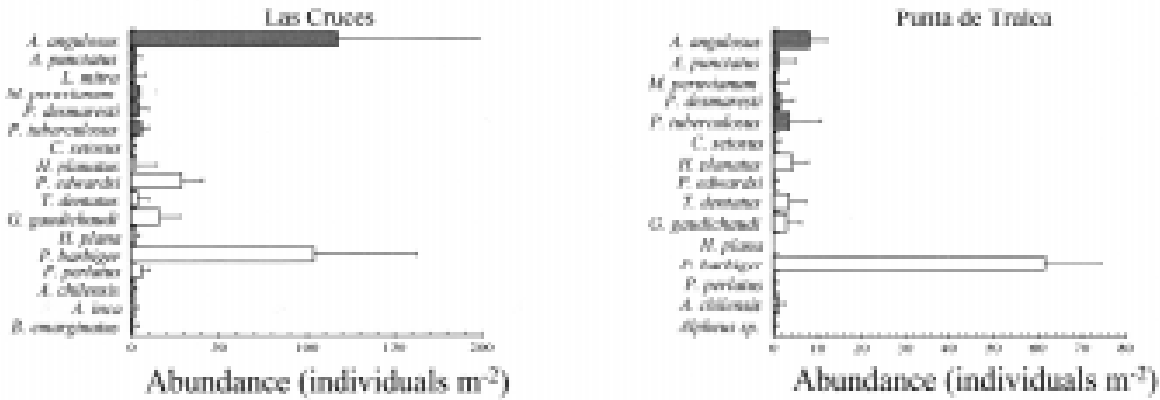

Fig. 3: Abundance of decapod crustaceans species found within $0.25 \mathrm{~m}^{2}$ square frames places over cobble substrata at the four study sites. Individuals were obtained through air-lift suction samples. Species were grouped in three major taxonomic divisions (Anomurans, Brachyurans, and shrimps). Error bars represent \pm 1 SE.

Abundancia de especies de crustáceos decápodos encontrados al interior de cuadrantes de $0.25 \mathrm{~m}^{2}$ ubicados sobre sustrato de bolones en cuatro sitios de estudio. Los individuos fueron obtenidos mediante el empleo de un succionador de fondo accionado por aire. Las especies se agruparon en tres divisiones taxonómicas mayores (Anomuros, Braquiuros, y Camarones). Las barras de error representan \pm 1 EE.

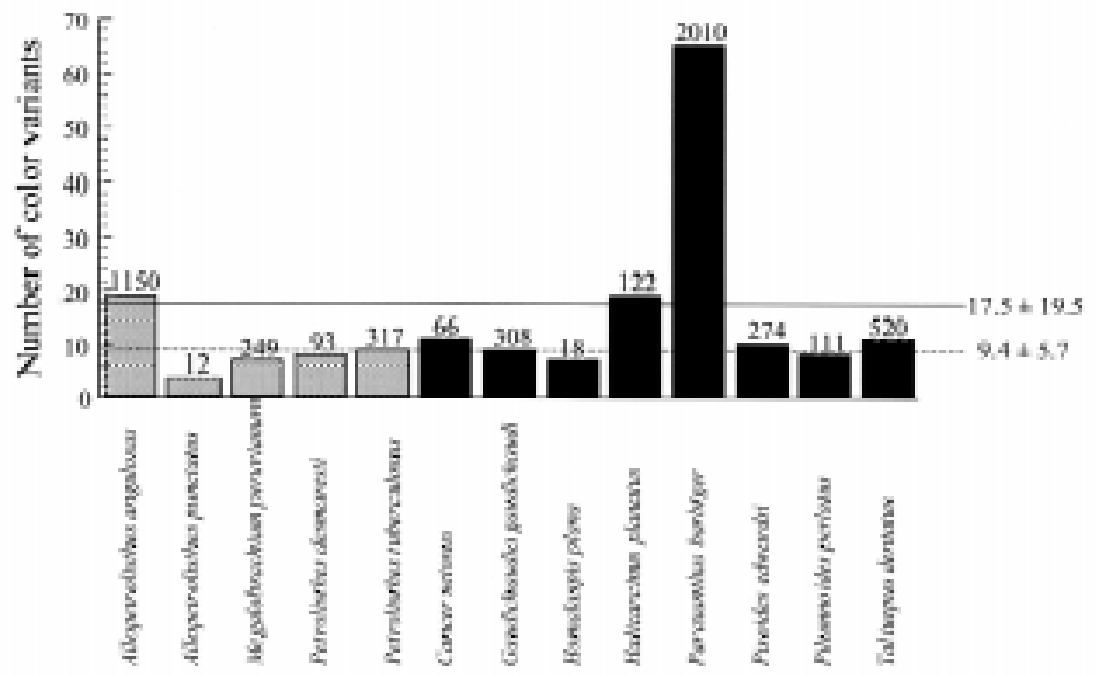

Fig. 4: Number of color variants displayed by all individuals belonging to the 13 decapod species (Anomurans and Brachyurans) obtained through suction samples. Numbers above bars represent the number of individuals of each species quantified. Horizontal lines represent the average number of color morphs of all brachyuran species (black) and anomurans (dashed) considered.

Número de variantes de coloración exhibido por todos los individuos pertenecientes a las 13 especies de decápodos (anomuros y braquiuros) obtenidos en las succiones de fondo. Los números sobre las barras representan el número de individuos cuantificados para cada especie. Líneas horizontales representan el número de morfos de coloración de todas las especies de braquiuros (negra) y anomuros (punteada) consideradas. 

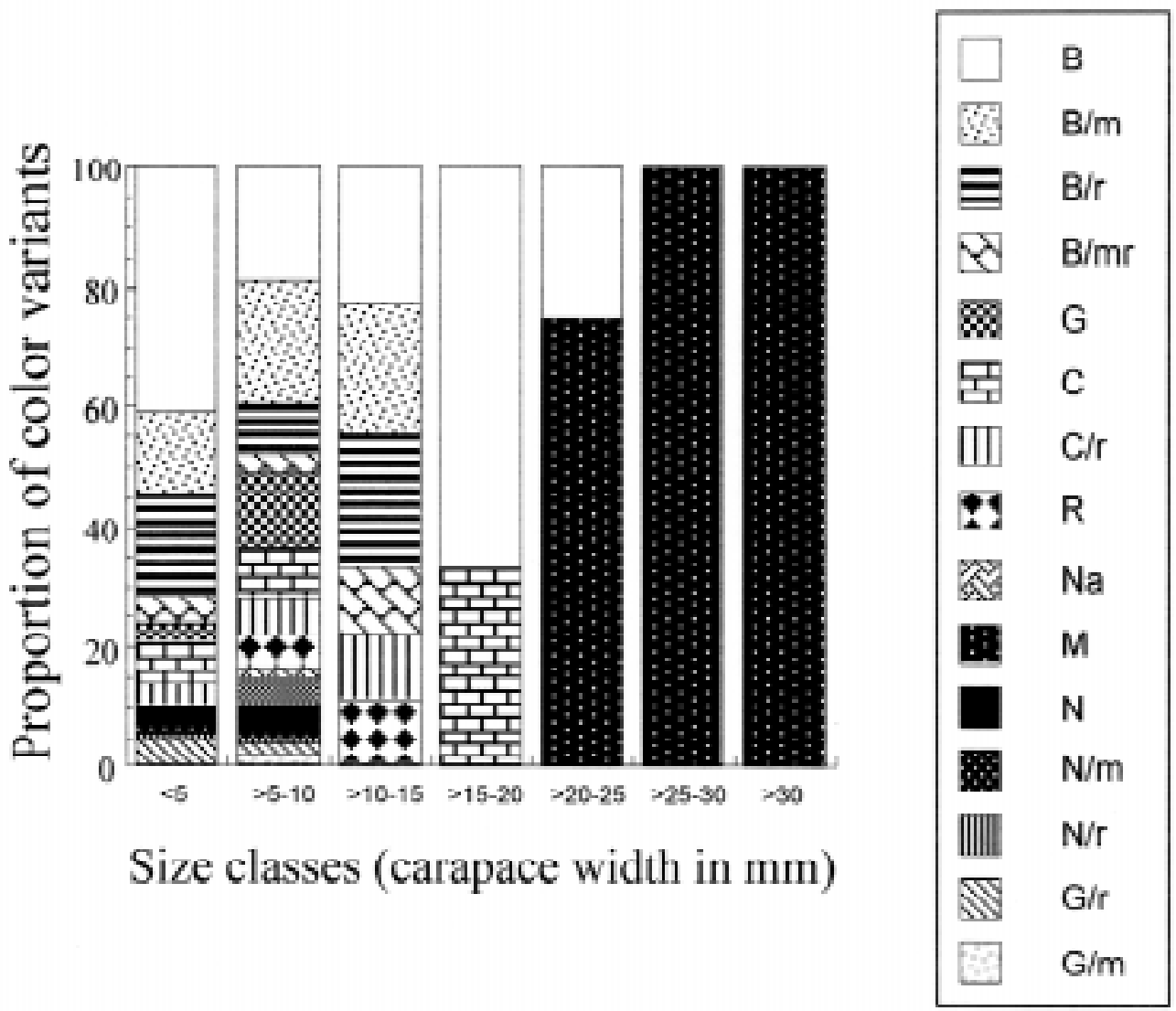

Fig. 5: Frequency of the different color variants (see Material and Methods) for individuals of Paraxanthus barbiger collected in natural cobble substrata at the Quintay site. Only the most common (15) color variants are shown, although a total of 65 were identified. Frequencies were plotted for different size classes of a total of 1,006 individuals considered: $\mathrm{B}=$ white, $\mathrm{B} / \mathrm{m}=$ white with $\mathrm{spots}, \mathrm{B} / \mathrm{r}=$ white with stripes, $\mathrm{B} / \mathrm{mr}=$ white with red spots, $\mathrm{G}=$ gray, $\mathrm{C}=$ brown, $\mathrm{C} / \mathrm{r}=$ brown with stripes, $\mathrm{R}=\mathrm{red}$, $\mathrm{Na}=$ orange, $\mathrm{M}=$ dark violet, $\mathrm{N}=$ black, $\mathrm{N} / \mathrm{m}$ = black with spots, $\mathrm{N} / \mathrm{r}=$ black with stripes, $\mathrm{G} / \mathrm{r}=$ gray with stripes, $\mathrm{G} / \mathrm{m}=$ gray with spots.

Frecuencia de los distintos variantes de coloración (ver Materiales y Métodos) para individuos de Paraxanthus barbiger colectados en sustrato natural de bolón en el sitio de Quintay. Solo se muestran los variantes de coloración más comunes (15), aunque se identificaron un total de 65. Las frecuencias se graficaron para distintas clases de tamaño de un total de 1.006 individuos considerados: $\mathrm{B}=$ blanco, $\mathrm{B} / \mathrm{m}=$ blanco con manchas, $\mathrm{B} / \mathrm{r}=$ blanco con $\mathrm{ray}$ as, $\mathrm{B} / \mathrm{mr}=$ blanco con manchas rojas, $\mathrm{G}=$ gris, $\mathrm{C}=$ café, $\mathrm{C} / \mathrm{r}=$ café con rayas, $\mathrm{R}=$ rojo, $\mathrm{Na}=$ naranja, $\mathrm{M}=$ morado, $\mathrm{N}=$ negro, $\mathrm{N} / \mathrm{m}=$ negro con manchas, $\mathrm{N} / \mathrm{r}=$ negro con rayas, $\mathrm{G} / \mathrm{r}=$ gris con rayas, $\mathrm{G} / \mathrm{m}=$ gris con manchas.

color morphs are exhibited by the smaller size classes as exemplified with P. barbiger (Fig. 5), which invariably turn into the adult coloration after a certain size. An almost identical pattern was described for Cancer irroratus (Say, 1817), a decapod species from the Western North Atlantic (Palma \& Steneck 2001), suggesting that this may be a common attribute during the early benthic stages of Brachyurans. In general, these findings are novel and for the benthic Decapods of Chile, the present work represents the first description of the existence of color-variable juveniles.

In general, and despite being a common and abundant group of crustaceans, little information is available with respect to the existence of color variability in Decapods (but see Hogarth 1978, Hacker \& Madin 1991, Barshaw \& Spanier 1994, Palma \& Steneck 2002). Moreover, and coincident with the aim of this research, scarce information exists on the anti-predatory value of this attribute. Considering the higher vulnerability of decapods while small (Wahle 1992, Fernández et al. 1993, Eggleston \& Armstrong 1995, Palma et al 1999, Palma \& Ojeda 2002), it is not surprising the occurrence of greater color variability in such individuals among the species analyzed here.

The existence of color variable individuals, especially among the smaller size classes in this 
study, supports the above explanation and strongly suggests that predation, particularly by fish, as the main process responsible for this pattern, however, there is a need to better understand the mechanisms involved. We did recognize several color morphs that were present in various proportions for the different species considered, however, we are aware that the presence of the different color patterns described could also represent a case of crypsis through disruptive coloration (sensu Merilaita 1998). This type of crypsis agrees with the highly heterogeneous habitat where these species are found. Nevertheless, and even though we are able to describe the existence of crypsis, the true mechanism by which the polymorphism present during the juvenile stages of these species is maintained remains a question. In addition it is important to know about the true identity of predators if the intention is to find an explanation for the variability in the expression of color morphs in Brachyurans. We consider that further experimental work should involve the recognition of behavioral aspects of these types of species, for example their rhythm of activity and the type of interaction with other decapods that inhabit the same environments.

\section{ACKNOWLEDGMENTS}

We thank the important field and laboratory assistance of S. Juárez, F. Martelli, A. Astorga, E. Poulin, M. Soto and M-L León. We also thank the comments by two anonymous reviewers. This research was supported by FONDECYT grant 3990032 to A.T.P.

\section{LITERATURE CITED}

BARSHAW DE \& E SPANIER (1994) Anti-predator behaviors of the Mediterranean slipper lobster, Scyllarides latus. Bulletin of Marine Science 55: 375-382.

BECK MW (1995) Size-specific shelter limitation in stone crabs: a test of the demographic bottleneck hypothesis. Ecology 76: 968-980.

CRUZ-RIVERA E (2001) Generality and specificity in the feeding and decoration preferences of three Mediterranean crabs. Journal of Experimental Marine Biology and Ecology 266: 17-31.

EGGLESTON DB \& DA ARMSTRONG (1995) Pre- and post-settlement determinants of estuarine Dungeness crab recruitment. Ecological Monographs 65: 193-216.

ENDLER JA (1978) A predator's view of animal color patterns. Evolutionary Biology 11:319-364.
ENDLER JA (1988) Frequency-dependent predation, crypsis and aposematic coloration. Philosophical Transactions of the Royal Society of London, Biological Sciences 319: 505-523.

ESPOZ CG, G GUZMÁN \& JC CASTILLA (1995) The lichen Thelidium litorale on shell of intertidal limpets: a case of lichen-mediated cryptic mimicry. Marine Ecology Progress Series 119: 191-197.

FERNÁNDEZ M, D ARMSTRONG \& O IRIBARNE (1993) First cohort of young-of-the-year Dungeness crab, Cancer magister, reduces abundance of subsequent cohorts in intertidal shell habitats. Canadian Journal of Fisheries and Aquatic Sciences 50: 2100-2105.

GUARINO SM, C GAMBARDELLA, M IANNIRUBERTO \& M DE NICOLA (1993) Colour polymorphisms in Idotea baltica from the Bay of Naples and its ecological significance. Journal of the Marine Biology Association of United Kingdom 73: 785-794.

HACKER SD \& LP MADIN (1991) Why habitat architecture and color are important to shrimp living in pelagic Sargassum: use of camouflage and plant-part mimicry. Marine Ecology Progress Series 70: 143-155.

HOGARTH PJ (1978) Variation in the carapace pattern of juvenile Carcinus meanas. Marine Biology 44: $337-$ 343.

MERILAITA S (1998) Crypsis through disruptive coloration in an isopod. Proceedings from the Royal Society of London, Series B 265: 1059-1064.

MERILAITA S, J TUOMI \& V JORMALAINEN (1999) Optimization of cryptic coloration in heterogeneous habitats. Biological Journal of the Linnean Society 67: 151-161.

PALMA AT \& RS STENECK (2001) Does variable coloration in juvenile marine crabs reduce risk of visual predation? Ecology 82: 2961-2967.

PALMA AT \& FP OJEDA (2002) Abundance, distribution and feeding patterns of a temperate reef fish in subtidal environments of the Chilean coast: the importance of understory algal turf. Revista Chilena de Historia Natural 75: 189-200.

PALMA AT, RA WAHLE \& RS STENECK (1998) Different early post-settlement strategies between American lobsters Homarus americanus and rock crabs Cancer irroratus in the Gulf of Maine. Marine Ecology Progress Series 162: 215-225.

PALMA AT, RS STENECK \& C WILSON (1999) Settlement-driven, multiscale demographic patterns of large benthic decapods in the Gulf of Maine. Journal of Experimental Marine Biology and Ecology 241: 107-136.

RETAMAL M (1981) Catálogo ilustrado de los crustáceos decápodos de Chile. Gayana Zoología (Chile) 44:1110.

STACHOWICZ JJ \& ME HAY (1996) Facultative mutualism between an herbivorous crab and a coralline alga: advantages of eating noxious seaweeds. Oecologia 105: 377-387.

SYSTAT (1992) Statistics, Version 5.2 edition. SYSTAT, Inc, Evanston, IL. 724 pp.

WAHLE RA (1992) Body-size dependent anti-predator mechanisms of the American lobster. Oikos 65: 5260 . 
WAHLE RA \& RS STENECK (1991) Recruitment habitats and nursery grounds of the American lobster Homarus americanus: a demographic bottleneck? Marine Ecology Progress Series 69: 231-243.

Associate Editors: Patricio Ojeda and Luis Ebensperger Received October 7, 2002; accepted March 28, 2003
WAHLE RA \& RS STENECK (1992) Habitat restrictions in early benthic life: experiments on habitat selection and in situ predation with the American lobster. Journal of Experimental Marine Biology and Ecology 157: 91-114.

ZAR JH (1999) Biostatistical analysis. Prentice-Hall, Upper Saddle River, New Jersey. 663 pp. 